Sains Malaysiana 47(3)(2018): 441-446

http://dx.doi.org/10.17576/jsm-2018-4703-03

\title{
Sunda Scops-Owl Density Estimation via Distance Sampling and Call Playback
}

(Anggaran Kepadatan Burung Hantu Jampuk melalui Jarak Pensampelan dan Panggilan Ulang Dengar)

\author{
Phillcaine Pilla, Chong LeOng Puan*, Voon-Ching Lim, Badrul AZHar \& Mohamed Zakaria
}

\begin{abstract}
Nocturnal birds in the tropics remain little studied primarily due to the logistical difficulties of surveying these birds at night. While call playback has been widely employed in the temperate regions, its practicality has not been adequately demonstrated on tropical owl species. This study aimed to test the feasibility of estimating the density of the Sunda scopsowl (Otus lempiji) in a lowland forest in Peninsular Malaysia based on call playback and distance sampling. From a total of 58 detections of the owl species from October 2012 to May 2013, 72.41\% (42 detections) were made when the birds were breeding. The densities of the owl were estimated at 1.6 individuals and 2.6 individuals per 10 ha based on spontaneous and provoked calls (i.e. before and after call playback), respectively. Broadcasting of the calls significantly increased the numbers of detections $\left(\chi^{2}=16.038, \mathrm{p}<0.001\right)$ during both breeding and non-breeding seasons of the birds. The combination of call playback and distance sampling improved the detectability as well as precision of the owl's density estimation and can be potentially applied on other little known owl species in Southeast Asia.
\end{abstract}

Keywords: Call playback; density estimation; distance sampling; Otus lempiji; vocalisation

\section{ABSTRAK}

Hanya sedikit kajian terhadap burung nokturnal di kawasan tropika dijalankan kerana masalah logistik untuk meninjau burung ini pada waktu malam. Walaupun panggilan ulang dengar telah digunakan secara meluas di rantau temperat namun tahap praktikalnya tidak digunakan ke atas spesies burung hantu tropika secukupnya. Kajian ini bertujuan untuk menguji kebolehlaksanaan menganggarkan ketumpatan burung hantu jampuk (Otus lempiji) di hutan tanah rendah di Semenanjung Malaysia berdasarkan panggilan ulang dengar dan jarak persampelan. Daripada sejumlah 58 spesies burung hantu yang dikesan dari Oktober 2012 hingga Mei 2013, 72.41\% (42 pengesanan) telah dibuat apabila burung membiak. Kepadatan burung hantu dianggarkan pada 1.6 individu dan 2.6 individu untuk setiap 10 ha berdasarkan panggilan spontan dan provokasi (sebelum dan selepas panggilan ulang dengar). Penyebaran panggilan dengan ketara meningkatkan bilangan pengesanan $\left(\chi^{2}=16.038, \mathrm{p}<0.001\right)$ semasa musim pembiakan dan bukan pembiakan burung. Gabungan panggilan ulang dengar dan jarak persampelan memperbaiki keterkesanan serta ketepatan kepadatan anggaran burung hantu dan berpotensi digunakan ke atas spesies burung hantu kurang diketahui di Asia Tenggara.

Kata kunci: Kepadatan jarak persampelan; panggilan ulang dengar; penyuaraan; Otus lempiji

\section{INTRODUCTION}

Assessing vocalisation is essential in owl censuses (Borges et al. 2004; Currie et al. 2002; Jacobsen et al. 2013) as owls are more conspicuous vocally than visually. Conventional sight and capture methods are often laborious and less effective particularly in nocturnal bird surveys, whereas surveys based on vocalisation are relatively practical in covering larger areas in less time (Hardouin et al. 2009; Nagy et al. 2012; Trejo \& Beaudoin 2011; Zuberogoitia et al. 2011). Vocalisation surveys (i.e. passive listening and/or active call broadcasting) are frequently used in detecting elusive species (Johnson et al. 1981; Marion et al. 1981) including owls which often react to the conspecific call playbacks (Pardieck et al. 1996; Wiens et al. 2011). These vocal responses from owls could also aid in assessing their sexes (Odom \& Mennil 2010; Takagi et al. 2007a) and breeding success (Hardouin et al. 2009).
To date, the distributions and densities of many owl species in different habitat types throughout the world have been assessed based on vocalisation. In Europe, examples include the Eurasian scops owl (Otus Scops) in semi-arid landscapes in Spain (Martínez et al. 2007), the Ural owl (Strix uralensis) in temperate, montane and Mediterranean forests in Croatia (Tutiš et al. 2009) and the little owl (Athene noctua) in agricultural areas in Denmark (Jacobsen et al. 2013). In North America, the barred owls (Strix varia) in bottomland forests (Winton \& Leslie 2004) and the eastern screech owl (Megascops asio) in suburban forest fragments (Nagy et al. 2012) have been similarly assessed. Elsewhere, similar playback methods were applied on the western burrowing owl (Athene cunicularia hypugaea) in native prairies in Canada (Shyry et al. 2001), the Puerto Rican screech owl (Otus nudipes) in continuous and fragmented subtropical forests in Puerto Rico (Pardieck 
et al. 1996) and the Christmas Island hawk owl (Ninox natalis) on Christmas Island (Hill \& Lill 1998). However, studies involving call playback are still very limited in the tropics (Borges et al. 2004; Enríquez-Rocha \& RangelSalazar 2001). In Southeast Asia, the vocal individuality of the Sunda scops-owl (Otus lempiji) was tested through call playback in Peninsular Malaysia (Yee et al. 2016), whereas the vocal responses of several owl species were used to assess their densities in a lowland forest in southern Thailand (Kemp et al. 2009).

In Malaysia, although a rich assemblage of owl species has been recorded (MNS-BCC 2015), there are only a few published works on these birds over the last four decades (Biun et al. 2006; Hamid et al. 2008; Marshall 1978; Najmi-Hanis et al. 2016; Wells 1986; Yee et al. 2016) with much of the emphasis given to the barn owl Tyto alba javanica, which is of economic interest with respect to biological control of agricultural rodent pests (Duckett 1991; Hafidzi et al. 2003; Lenton 1984; Puan et al. 2011). The lack of ecological studies on the Malaysian owls is partly due to the difficulties in surveying these nocturnal birds. To the best of our knowledge, there is no published work on the assessment of owl distribution or density using vocalisation-based method in Malaysia. Hence, we examined the potential of such method in estimating the density of the Sunda scops-owl, a common owl species in Peninsular Malaysia, through passive listening and call playback. In particular, we asked whether both methods yield comparable density estimates (similar to EnríquezRocha \& Rangel-Salazar 2001; Loyn et al. 2001; Trejo \& Beaudoin, 2011; Wiens et al. 2011) and whether the estimates differ between breeding and non-breeding seasons (Wiens et al. 2011; Zuberogoitia et al. 2011). As such, our comparative study also provided insights into Sunda scops-owl's density in an isolated dipterocarp forest in Peninsular Malaysia.

\section{METHODS \\ STUDY SITE}

The study was conducted in Ayer Hitam Forest Reserve ( $2^{\circ} 80^{\prime} \mathrm{N}, 101^{\circ} 39^{\prime} \mathrm{E}$; Figure 1), a dipterocarp forest located approximately $30 \mathrm{~km}$ southwest of Kuala Lumpur, Peninsular Malaysia. The forest was selectively logged before 1965 (Zakaria \& Topani 1999) and it is currently an isolated forest of about 1,176 ha surrounded by residential areas. The daily average temperature in the area was $26.6^{\circ} \mathrm{C}$ whereas the relative humidity was $83 \%$ (Syafinie $\&$ Ainuddin 2013). The geology of the forest comprises igneous rock with granite. Zakaria and Rahim (1999) reported 160 bird species (from 38 families) including the Sunda scops-owl which breeds locally from February to April, sometimes extending to June or July (sensu Konig \& Weick 2008).

\section{CALL PLAYBACK}

Surveys of the Sunda scops-owls were made using call playback from 6 October 2012 to 12 May 2013, which covered both breeding and non-breeding seasons. Playback was made using a 10-Watt RadioShack Powerhorn 322038A connected to a MP3 player that was placed at chest height and was rotated at $360^{\circ}$ when the call was played. Prior to the actual survey, a pilot study was conducted to ensure that the sound can be heard at least $100 \mathrm{~m}$ from

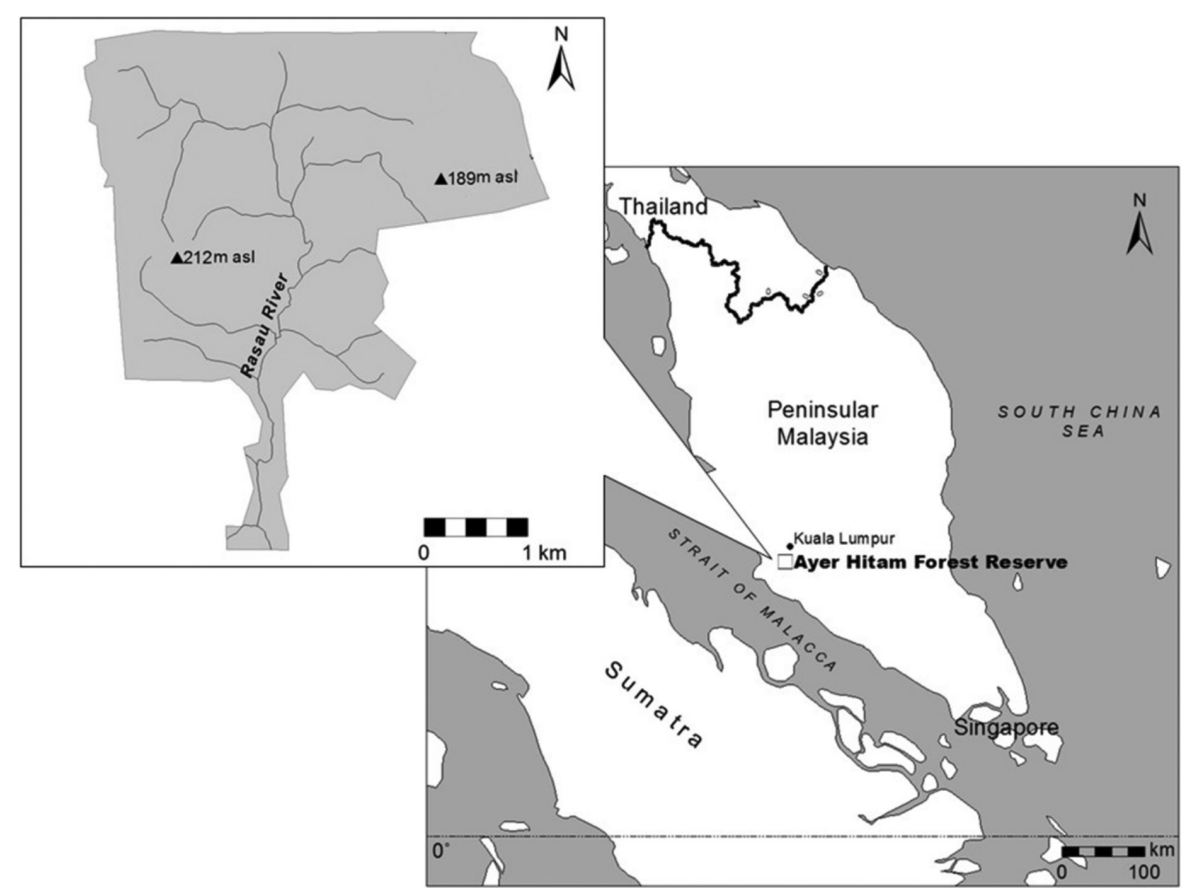

FIGURE 1. Location of Ayer Hitam Forest Reserve, Selangor, Peninsular Malaysia 
pre-determined survey points and the vocal responses from the owls were recorded.

A total of 38 permanent survey points marked with coloured flags were established in the forest. Although constrained by night-time accessibility, attempts were made to ensure that the minimum distance between points was at least $200 \mathrm{~m}$ considering the home range size estimated for the same species in the same study site (Najmi-Hanis et al. 2016). The surveys were carried out at 1830-0000 $\mathrm{h}$ which covered the period when the majority of detections are expected (Takats et al. 2001). At each point, a surveyor first listened for $10 \mathrm{~min}$ before broadcasting a call (70-80 dB) for $2 \mathrm{~min}$, followed by another $10 \mathrm{~min}$ of listening. Once an owl was detected, broadcasting was immediately stopped to prevent the bird moving away from its original perch (Borges et al. 2004). The call direction was measured using a compass and the radial distance of each bird was estimated from the survey point (Pyke \& Recher 1985) by only one observer (PP). The 38 points were surveyed four times, i.e. twice during the non-breeding season (from October 2012 to January 2013) and twice during the breeding season (from February to May 2013).

\section{DATA ANALYSIS}

We categorised the detections of the owls into: Those that were obtained based on call playback; and those that were detected through spontaneous calls, prior to a call playback. We estimated the density of the owls using Distance version 6.2 (Buckland et al. 2001; Thomas et al. 2010). The halfnormal distribution with cosine adjustment function was selected as the detection function. We did not truncate the data due to limited observations, which was indeed less than the minimum number of 80 observations required for adequate density estimation via point counts (Buckland et al.2001). Nonetheless, bootstrap resampling procedure of 1000 iterations was performed to improve the spread of the confidence intervals. Chi-square test was used to examine if there was an association between the number of owls detected with respect to the use of call playbacks during breeding and non-breeding seasons. This was followed by a post hoc analysis to determine where the significant differences were.

\section{RESULTS}

A total of 58 detections of Sunda scops-owls (covering $38.16 \%$ of the total 152 survey points over eight months) were made. Of these, 42 detections $(72.41 \%)$ were obtained during the breeding season. Regardless of breeding and nonbreeding seasons (when data was pooled), the estimated owl density was 1.6 birds and 2.6 birds per 10 ha based on spontaneous and provoked calls, respectively. During breeding season, the densities of the birds were estimated to be 1.8 individuals per 10 ha based on spontaneous calls and 2.7 individuals per 10 ha through call playback. For non-breeding season, the owl density was 1.3 individuals per 10 ha based on both spontaneous calls and call playback method.

Through spontaneous calls alone, no significant association was found between the number of owls detected during breeding and non-breeding seasons $\left(\chi^{2}=2.676\right.$, $p=0.102)$. However, we found a significant association between the number of owls detected with call playbacks during breeding and non-breeding seasons $\left(\chi^{2}=16.038\right.$, $p<0.001)$. The results of the post hoc analysis indicated that the number of owls detected was significantly higher when a call playback was used during both seasons. Out of the 58 detections, about $48.28 \%$ of the responses were obtained when playbacks of calls were made.

\section{DISCUSSION}

The density estimates for Sunda scops-owls in our study area varied slightly according to the breeding period of the birds and the use of call playbacks (Table 1). Our estimate of the owl density through distance sampling (i.e. one to two birds per every $10 \mathrm{ha}$ ) is congruent with Najmi-Hanis et al. (2016) who estimated the home range of $2.40 \pm 0.28$ to $4.00 \pm 0.78$ ha pre individual for the same species at the same study site. When we analysed the data according to the breeding and non-breeding seasons, the estimated owl density was slightly higher during breeding season than during non-breeding season.

Our study also demonstrated that call playback provoked the owls to respond (Tutiš et al. 2009; Winton \& Leslie 2004) and consequently increased their detection in the forest regardless of the breeding and non-breeding seasons. Higher vocal responses following

TABLE 1. Densities estimated for Sunda scops-owl based on spontaneous and provoked calls, and breeding and non-breeding seasons

\begin{tabular}{lcccccc}
\hline & \multicolumn{3}{c}{$\begin{array}{c}\text { Spontaneous calls } \\
\text { (without call playbacks) }\end{array}$} & \multicolumn{2}{c}{$\begin{array}{c}\text { Spontaneous and provoked calls } \\
\text { (with call playbacks) }\end{array}$} \\
\cline { 2 - 7 } Statistics & $\begin{array}{c}\text { Breeding \& } \\
\text { non-breeding }\end{array}$ & Breeding & Non-breeding & $\begin{array}{c}\text { Breeding \& } \\
\text { non-breeding }\end{array}$ & Breeding & Non-breeding \\
\hline Density (Individuals/ha) & 0.159 & 0.175 & 0.125 & 0.262 & 0.274 & 0.129 \\
Bootstrapped 95\% CI & $0.107-0.236$ & $0.110-0.276$ & $0.065-0.242$ & $0.201-0.343$ & $0.176-0.454$ & $0.072-0.229$ \\
CV (\%) & 19.44 & 22.30 & 29.16 & 13.46 & 15.82 & 27.62 \\
$\mathrm{n}$ & 30 & 21 & 9 & 58 & 42 & 16 \\
\hline
\end{tabular}


call broadcasting (Braga \& Motta-Junior 2009) may be attributed to territorial and/or courtship behaviour where individual birds would react upon hearing another bird within their territories (Currie et al. 2002; Haug \& Didiuk 1993; Kemp et al. 2009; Trejo \& Beaudoin 2011; Wiens et al. 2011). Hence, the call playback method could increase the detection of the owls compared to passive listening for spontaneous calls (Braga \& Motta-Junior 2009; Hannah 2009; Haug \& Didiuk 1993; Kissling et al. 2010) besides minimising the false absences of silent individuals. Moreover, the call playback method could increase the precision in density estimation (Braga \& Motta-Junior 2009), as indicated by smaller coefficients of variation (CV) derived relative to that of silent listening. However, it should be noted that the CV was only less than $20 \%$, indicating higher precision in estimation when data was pooled.

Vocal responses of owls to call playbacks have been demonstrated to vary between breeding and non-breeding seasons (Mori et al. 2014; Wiens et al. 2011; Zuberogoitia et al. 2011). The vocal territorial activity is greater during breeding season but decreases during non-breeding season (Hardouin et al. 2009). Owls tend to display territorial behaviour during breeding season by responding vocally to warn intruders (Haug \& Didiuk 1993; Mori et al. 2014; Moulton et al. 2004) and protect their nest (Mori et al. 2014; Moulton et al. 2004). Such greater vocal response can also be observed during early breeding season which is likely due to territorial and/or nest establishment and defence (Boal \& Bibles 2001; Mori et al. 2014; Moulton et al. 2004). Therefore, broadcasting conspecific calls during the breeding season could provoke individuals to be more aggressive in responding vocally. However, our study showed that a significant numbers of the Sunda scops-owls were detected when call playback was used regardless of breeding or non-breeding season, consequently suggested that the Sunda scops-owl may be territorial even during non-breeding season.

For many owl species, males actively display vocal activities to defend their territory (Currie et al. 2004; Moulton et al. 2004; Takagi et al. 2007b) and attract mates (Boal \& Bibles 2001; Jacobsen et al.2013). Owls tend to be more vocally responsive during the breeding season (Haug \& Didiuk 1993; Moulton et al. 2004) but such behaviour decreases throughout the nesting season (Boal \& Bibles 2001). Males may cease singing almost immediately after pairing in courtship (Konig \& Weick 2008) while females may become less vocally responsive during the incubation period (Haug \& Didiuk 1993; Takagi et al. 2007a). This is likely to happen when territories and nest have already been established and thus conspecific intruders may no longer be a threat. However, due to the limited information on the vocal differences between the sexes (Yee et al. 2016), we are unable to determine if there was a sexual-related bias in density estimation (Stanbury \& Gregory 2009). Moreover, we did not estimate the density of the owls based on different breeding stages over the survey period due to the lack of detailed information with respect to the breeding ecology of the focal species. These aspects should be further examined in future studies.

Broadcasting bird calls may also cause either overestimation or underestimation of the bird's density. Density overestimation may occur when: Individuals lured by call playback moved to a different location (Moulton et al. 2004; Wiens et al. 2011) and thus counted more than once (Borges et al. 2004; Hannah 2009) and/or; An owl species may have different vocal responses to playback and this can influence the actual count (Borges et al. 2004; Wiens et al. 2011). On the other hand, underestimation of density may occur when certain individuals did not react to call playback (Hannah 2009; Haug \& Didiuk 1993; Takagi et al. 2007a). In our study, several measures were taken to minimise the risk of density overestimation such as positioning the speaker at chest level and rotating it at $360^{\circ}$ to ensure the call was broadcasted to all directions and within the forest understory level at which the owls were active (Konig \& Weick 2008). We also set the range of radial distance from survey points at $100 \mathrm{~m}$ which owls were expected to hear the call playbacks (Borges et al. 2004; Hannah 2009). Broadcasting was also stopped immediately once an owl was detected to prevent the individual from moving away from its original perch (Borges et al. 2004).

Our study is among the first available in Southeast Asia to demonstrate the practicality of using vocalisation-based method in estimating the density of tropical owl species and their vocal responsiveness. Our combined methods of distance sampling and call playback provided better density estimation for the Sunda scops-owl in comparison to passive listening for spontaneous calls. Broadcasting a conspecific call could also provoke vocal responses from the owls, even during the non-breeding season. Therefore, we proposed the call playback coupled with distance sampling for further ecological study on other elusive and little known tropical owl species such as the Near Threatened and vocally distinctive reddish scops owl and Mantanani scops owl Otus mantananensis).

\section{ACKNOWLEDGEMENTS}

This study was financially supported by Universiti Putra Malaysia through the Research University Grant Scheme (Project No.: 03-01-11-1151RU) and partly by the Malaysian Nature Society (Perak Branch) through the Tan Kean Cheong Bird Conservation Memorial Fund. We thank the Forest and Plantation Section, Faculty of Forestry, Universiti Putra Malaysia for giving the permission to conduct the research in the study area and the Department of Wildlife and National Parks Malaysia for the permission to conduct the owl survey. We appreciate the help from Nornajmi Hanis Zolkanain, Tony Austin Sharif @ Ukang, Balantine Pungga and Chakrin Utit for the field work and Muhammad Syafiq Yahya for sorting out the data. We appreciate the comments from reviewers which improved the manuscript substantially. 


\section{REFERENCES}

Biun, A., Lakim, M.B. \& Davison, G.W.H. 2006. Spread of Tyto capensis (Smith) 1834 to Borneo. Sabah Parks Nature Journal 7: 45-48.

Boal, C.W. \& Bibles, B.D. 2001. Responsive of elf owls to conspecific and great horned owl calls. Journal of Field Ornithology 72(1): 66-71.

Borges, S.H., Henriques, L.M. \& Carvalhaes, A. 2004. Density and habitat use by owls in two Amazonian forest types. Journal of Field Ornithology 75(2): 176-182.

Braga, A.C.R. \& Motta-Junior, J.C. 2009. Weather conditions and moon phase influence on tropical screech owl and burrowing owl detection by playback. Ardea 97(4): 395-401.

Buckland, S.T., Anderson, D.R., Burnham, K.P., Laake, J.L., Borchers, D.L. \& Thomas, L. 2001. Introduction to Distance Sampling: Estimating Abundance of Biological Populations. Oxford: Oxford University Press. p. 432.

Currie, D., Fachette, R., Millet, J., Hoareau, C. \& Shah, N.J. 2004. The distribution and population of the Seychelles (barelegged) scops-owl Otus insularis on Mahé: consequences for conservation. Ibis 146: 27-37.

Currie, D., Millett, J., Hill, M. \& Shah, N.J. 2002. Factors affecting the response of Seychelles scops-owl Otus insularis to playback of conspecific calls: Consequences for monitoring and management. Bird Conservation International 12: 353364.

Duckett, J.E. 1991. Management of the barn owl (Tyto alba javanica) as a predator of rats in oil palm (Elaeis guineensis) plantations in Malaysia. Birds of Prey Bulletin 4: 11-23.

Enríquez-Rocha, P.L. \& Rangel-Salazar, J.L. 2001. Owl occurrence and calling behavior in a tropical rainforest. Journal of Raptor Research 35(2): 107-114.

Hafidzi, M.N., Hamzah, M.H. \& Jamaluddin, M.L. 2003. Ranging behaviour of Tyto alba in a ricefield using radio telemetry. Malaysian Applied Biology Journal 32: 45-49.

Hamid, N.H., Hafidzi, M.N., Ismail, S.T. \& Wahab, M.A.A. 2008. The eastern grass owl Tyto (capensis) longimembris in Sabah, Malaysia (Borneo). BirdingASIA 9: 88-89.

Hannah, K.C. 2009. Call playbacks increase detection rates of northern hawk owl in recent burns. Journal of Raptor Research 43(3): 241-244.

Hardouin, L.A., Bretagnolle, V., Tabel, P., Bavoux, C., Burneleau, G. \& Reby, D. 2009. Acoustic cues to reproductive success in male owl hoots. Animal Behaviour 78: 907-913.

Haug, E.A. \& Didiuk, A.B. 1993. Use of recorded calls to detect burrowing owls. Journal of Field Ornithology 64(2): 188194.

Hill, F.A.R. \& Lill, A. 1998. Density and total population estimates for the threatened Christmas Island hawk owl Ninox natalis. Eти 98: 209-220.

Jacobsen, L.B., Sunde, P., Rahbek, C., Dabelsteen, T. \& Thorup, K. 2013. Territorial calls in the little owl (Athene noctua): Spatial dispersion and social interplay. Ornis Fennica 90: 41-49.

Johnson, R.R., Brown, B.T., Haight, L.T. \& Simpson, J.M. 1981. Playback recordings as a special avian censusing technique. In Estimating the Numbers of Terrestrial Birds, edited by Ralph, C.J. \& Scott, J.M. Lawrence: Allen Press. pp. 68-75.

Kemp, A., Kemp, M. \& Thong-Aree, S. 2009. Surveys of nocturnal birds at Bala rainforest, sourthern Thailand. Forktail 25: 117-124.

Kissling, M.L., Lewis, S.B. \& Pendleton, G. 2010. Factors influencing the detectability of forest owls in southeastern Alaska. The Condor 112(3): 539-548.
Konig, C. \& Weick, F. 2008. Owls of the World.2nd ed. London: Christopher Helm Publishers. p. 528.

Lenton, G.M. 1984. The feeding and breeding ecology of barn owls Tyto alba in Peninsular Malaysia. Ibis 126: 551-575.

Loyn, R.H., McNabb, E.G., Volodina, L. \& Willig, R. 2001. Modelling landscape distributions of large forest owls as applied to managing forests in north-east Victoria, Australia. Biological Conservation 97: 361-376.

Marion, W.R., O’Meara, T.E. \& Maehr, D.S. 1981. Use of playback recordings in sampling elusive or secretive birds. In Estimating the Numbers of Terrestrial Birds, edited by Ralph, C.J. \& Scott, J.M. Lawrence: Allen Press. pp. 81-85.

Marshall, J.T. 1978. Systematics of smaller Asian night birds based on voice. Ornithological Monographs 25: 1-58.

Martínez, J.A., Zuberogoitia, I., Martínez, J.E., Zabala, J. \& Calvo, J.F. 2007. Patterns of territory settlement by Eurasian scops-owls (Otus scops) in altered semi-arid landscapes. Journal of Arid Environments 69: 400-409.

MNS-BCC. 2015. A Checklist of the Birds of Malaysia. 2nd ed., MNS Conservation Publication No. 14. Kuala Lumpur: Malaysian Nature Society. p. 60.

Mori, E., Menchetti, M. \& Ferretti, F. 2014. Seasonal and environmental influences on the calling behaviour of Eurasian scops-owls. Bird Study 61: 277-281.

Moulton, C.E., Brady, R.S. \& Belthoff, J.R. 2004. Territory defence of nesting burrowing owls: Responses to simulated conspecific intrusion. Journal of Field Ornithology 75(3): 288-295.

Najmi-Hanis, Z., Puan, C.L., Zakaria, M. \& Azhar, B. 2016 Home range and activity patterns of Sunda scops-owl in Peninsular Malaysia. Raffles Bulletin of Zoology 64: 28-32.

Nagy, C., Bardwell, K., Rockwell, R.F., Christie, R. \& Weckel, M. 2012. Validation of a citizen science-based models of site occupancy for eastern screech owls with systematic data in suburban New York and Connecticut. Northeastern Naturalist 19(6): 143-153.

Odom, K.J. \& Mennil, D.J. 2010. A quantitative description of the vocalizations and vocal activity of the barred owl. The Condor 112(3): 549-560.

Pardieck, K.L., Meyers, J.M. \& Pagan, M. 1996. Surveys of Puerto Rican screech owl populations in large-tract and fragmented forest habitats. Wilson Bulletin 108(4): 776-782.

Puan, C.L., Goldizen, A.W., Zakaria, M., Hafidzi, M.N. \& Baxter, G.S. 2011. Absence of differential predation on rats by Malaysian barn owls in oil palm plantations. Journal of Raptor Research 45: 71-78.

Pyke, G.H. \& Recher, H.F. 1985. Estimated forest bird densities by variable distance point counts. Australian Wildlife Research 12: 307-319.

Shyry, D.T., Wellicome, T.I., Schmutz, J.K., Erickson, G.L., Scobie, D.L., Russell, R.F. \& Martin, R.G. 2001. Burrowing owl population-trend surveys in Southern Alberta: 19912000. Journal of Raptor Research 35(4): 310-315.

Stanbury, A. \& Gregory, R. 2009. Exploring the effects of truncated, pooled and sexed data in distance sampling estimation of breeding bird abundance. Bird Study 56(3): 298-309.

Syafinie, A.M. \& Ainuddin, A.N. 2013. Biomass and carbon estimation of Eugeissona tristis. Sains Malaysiana 42(10): 1461-1466.

Takagi, M., Akatani, K., Matsui, S. \& Saito, A. 2007a. Status of the Daito scops owl on Minami-Daito Island, Japan. Journal of Raptor Research 41(1): 52-56. 
Takagi, M., Akatani, K., Saito, A. \& Matsui, S. 2007b. Drastic decline of territorial male Daito Scops-owls on Minami-Daito Island in 2006. Ornithological Science 6(1): 39-42.

Takats, D.L., Francis, C.M., Holroyd, G.L., Duncan, J.R., Mazur, K.M.R., Cannings, J., Harris, W. \& Holt, D. 2001. Guidelines for Nocturnal Owl Monitoring in North America. Edmonton: Beaverhill Bird Observatory and Bird Studies Canada. p. 32.

Thomas, L., Buckland, S.T., Rexstad, E.A., Laake, J.L., Strindberg, S., Hedley, S.L., Bishop, J.R.B., Marques, T.A. \& Burnham,K.P. 2010. Distance software: Design and analysis of distance sampling surveys for estimating population size. Journal of Applied Ecology 47(1): 5-14.

Trejo, A. \& Beaudoin, F. 2011. Response of Rufous-legged owls to broadcast of conspecific calls in southern temperate forests of Argentina. Journal of Raptor Research 45(3): 267-271.

Tutiš, V., Radović, D., Ciković, D., Barišić, S. \& Kralji, J. 2009. Distribution, density and habitat relationships of the Ural owl Strix uralensis macroura in Croatia. Ardea 97(4): 563-570.

Wells, D.R. 1986. Further parallels between the Asian bay owl Phodilus badius and Tyto species. Bulletin of the British Ornithologists' Club 106: 12-15.

Wiens, J.D., Anthony, R.G. \& Forsman, E.D. 2011. Barred owl occupancy surveys within the range of the northern spotted owl. Journal of Wildlife Management 75(3): 531-538.

Winton, B.R. \& Leslie Jr., D.M. 2004. Density and habitat associations of barred owls at the edge of their range in Oklahoma. Southeastern Naturalist 3(3): 475-482.

Yee, S.A., Puan, C.L., Chang, P.K. \& Azhar, B. 2016. Vocal individuality of Sunda scops-owl (Otus lempiji) in Peninsular Malaysia. Journal of Raptor Research 50(4): 379-390.

Zakaria, M. \& Rahim, A. 1999. Bird species composition in Ayer Hitam Forest, Puchong, Selangor. Pertanika Journal of Tropical Agriculture Science 22(2): 95-104.

Zakaria, M. \& Topani, R. 1999. Abundance of primates in Ayer Hitam Forest, Puchong, Selangor. Pertanika Journal of Tropical Agricultural Science 22: 105-109.
Zuberogoitia, I., Zabala, H. \& Martínez, J.E. 2011 . Bias in little owl population estimates using playback techniques during surveys. Animal Biodiversity and Conservation 34(2): $395-$ 400 .

Phillcaine Pilla, Chong Leong Puan*, Badrul Azhar \& Mohamed Zakaria

Faculty of Forestry, Universiti Putra Malaysia 43400 UPM Serdang, Selangor Darul Ehsan Malaysia

Chong Leong Puan*

Institute of Tropical Forestry and Forest Products (INTROP) Universiti Putra Malaysia 43400 UPM Serdang, Selangor Darul Ehsan Malaysia

Chong Leong Puan* \& Badrul Azhar

Biodiversity Unit, Institute of Bioscience

Universiti Putra Malaysia

43400 UPM Serdang, Selangor Darul Ehsan Malaysia

Voon-Ching Lim

Institute of Biological Sciences, Faculty of Sciences University of Malaya, 50603 Kuala Lumpur Malaysia

*Corresponding author; email: chongleong@upm.edu.my

Received: 21 April 2017

Accepted: 25 September 2017 